\title{
Красное вино: химический состав, антиоксидантная активность, влияние на здоровье человека
}

\author{
А. Я. Яшин, К. Х.н., Я. И. Яшин, д. Х.н., А. Н. Веденин, \\ ООО «Интерлаб", Москва \\ yashin@interlab.ru
}

УДК 543

Статья получена 14.10.2019

Принята к публикации 15.12.2019

\begin{abstract}
Представлен обзор литературы, посвященной одному из самых древних напитков вину. Особое внимание уделено красному виноградному вину, которое содержит много различных полезных веществ, а самое ценное в его составе - витамины, микроэлементы и антиоксиданты. Современные аналитические методы, в первую очередь хроматография и масс-спектрометрия, позволили установить химический состав различных вин. Определена также антиоксидантная активность разных марок и установлено, что у красного вина она на порядок выше, чем у белого за счет использования при его производстве кожицы и виноградных косточек. Проведены измерения суммарного содержания антиоксидантов более чем в 80 образцах красных вин амперометрическим методом. Авторы проанализировали результаты и пришли к выводу, что по значениям антиоксидантной активности можно также судить о подлинности вин. Важный раздел обзора - обсуждение влияния потребления красного вина на здоровье человека. Отмечено, что умеренное потребление красного вина может снижать риск многих заболеваний, в том числе сердечно-сосудистых, онкологических, нейродегенеративных, диабета второго типа и др. Красное вино подавляет окислительный стресс, который считают предшественником многих болезней
\end{abstract}

\section{Химический состав красного вина}

Красное вино имеет сложный химический состав, оно содержит более 1000 соединений. Для анализа вина используется весь арсенал современных аналитических методов (табл. 1): молекулярная спектроскопия, масс-спектрометрия, массспектрометрия с индуктивно связанной плазмой, атомноабсорбционная спектроскопия, ЯМР, электрохимические методы, капиллярный электрофорез и др.

Чаще применяются методы хроматографии: газовая (ГХ), высокоэффективная жидкостная (ВЭЖХ), ионная (ИХ), гель-проникающая, ион-эксклюзионная и другие с разными детектирующими системами [16-40]. Самый общий
Таблица 1. Методы анапиза красного вина

\begin{tabular}{|c|c|c|}
\hline № & Название методов & Ссылки \\
\hline 1 & Молекулярная спектроскопия & 1 \\
\hline 2 & Масс-спектрометрия (МС) & 17 \\
\hline 3 & МС с индуктивно связанной плазмой & 1,29 \\
\hline 4 & Атомно-абсорбционная спектроскопия & 16 \\
\hline 5 & ЯMP & 31 \\
\hline 6 & Электрохимические методы & 28 \\
\hline \multirow[t]{2}{*}{7} & Капиллярный электрофорез & 24 \\
\hline & Методы хроматографии & \\
\hline 8 & Газовая хроматография (ГХ) & 20,30 \\
\hline 9 & $\Gamma \mathrm{X}-\mathrm{MC}$ & 18,35 \\
\hline 10 & Высокоэффективная жидкостная хроматография (ВэжХ) & $16,21,25,27,33,38$ \\
\hline 11 & BЭЖX-MC & 22 \\
\hline 12 & УльтраВЭЖХ & 37 \\
\hline 13 & Ионная хроматография & 34 \\
\hline 14 & Гель-проникающая хроматография & 26 \\
\hline 15 & Ион-эксклюзионная & 19 \\
\hline
\end{tabular}


Таблица 2. Состав красного вина

\begin{tabular}{|c|c|c|c|}
\hline & & Содержание & Ссылка \\
\hline 1. & Полифенольные соединения & бг/л & \\
\hline & Флавоноиды, флавонолы: кверцетин, кемпферол, рутин, мирицетин, изорамнетин & До 50 мг/л & $\begin{array}{l}22,25 \\
27,38,44\end{array}$ \\
\hline & Флаванолы: катехин, эпикатехин & & 27,28 \\
\hline & Антоцианины: дельфинидин-3-моноглюкозид, малвидин-3-глюкозид & $25 \mathrm{мг/л}$ & 26 \\
\hline & Стильбены: транс-ресвератрол & $0,8-24,7$ мг/л & $16,24,36$ \\
\hline & Гидроксикоричные кислоты: кофейная, кумаровая, феруловая & & 37 \\
\hline & Гидроксибензойные кислоты: п-гидроксибензойная, галловая, сиреневая, прокатехиновая & & 37 \\
\hline & Проантоцианидины, танины & & 26,33 \\
\hline 2. & $\begin{array}{l}\text { Органические кислоты (мг/л): } \\
\text { винная - 362-3613; яблочная - 60-639; молочная-7-1980; уксусная - 9-1021; } \\
\text { лимонная-9-624; щавелевая - до 150; янтарная - 250-1500 }\end{array}$ & & $16,19,21$ \\
\hline 3. & Углеводы-моносахара: глюкоза, фруктоза, арабиноза & $500-1260$ мг/л & 41 \\
\hline 4. & $\begin{array}{l}\text { Азотосодержащие соединения: } \\
\text { доля пептидов - 55\%, свободных аминокислот - 40\%, белков-3\% }\end{array}$ & $70-80 \mathrm{мг/л}$ & 41 \\
\hline 5. & $\begin{array}{l}\text { Алифатические спирты: } \\
\text { пропиловый, бутиловый, изобутиловый, амиловый, изоамиловый }\end{array}$ & $300-600 \mathrm{мг/л}$ & 41 \\
\hline 6. & $\begin{array}{l}\text { Монотерпеновые: } \\
\text { гераниол, линалоол, альфа-терпинол, эндиол, героил, гераниевая кислота }\end{array}$ & & 23 \\
\hline 7. & Серасодержащие соединения, всего идентифицировано 46 соединений & & 20 \\
\hline 8. & $\begin{array}{l}\text { Витамины (мг/л): } \\
\text { C-1,5-15; А (каротин)-0,12-0,2; E-1,17-1,19; В1 (тиамин)-0,01; } \\
\text { В2 (рибофлавин)-0,1-0,2; В5-0,3-0,5; В6 (пиридоксин)-0,1-0,4 }\end{array}$ & & 41 \\
\hline 9. & $\begin{array}{l}\text { Альдегиды: } \\
\text { уксусный, пропионовый; альдегиды фуранового ряда: фурфурол, оксиметилфурфурол }\end{array}$ & До 30 мг / л & 42 \\
\hline 10. & Эфиры жирных кислот (мг / ): этиловые эфиры - 50-200; этиловые эфиры оксикислот & $100-300 \mathrm{мг/л}$ & 41 \\
\hline 11. & $\begin{array}{l}\text { Минеральные примеси (мг/л): } \\
\text { Al-0,3-1,1; B4-12; Ba -0,01-0,19; Ca -41-102; Cu -0,03-0,26; Fe-1,2-4,6; K-1 040-1450; } \\
\text { Mg-84-131; Mn-0,9-1,9; Na-8,6-45; P-236-629; S-202-339; Si - 5-22; Zn-0,4-2,2 }\end{array}$ & Всего 1,5-3 г/л & 16,29 \\
\hline 12. & Глицерин, 2,3-бутандиол, 1,2- пропандиол & $0,26-16,4$ г/л & 18 \\
\hline 13. & Мелатонин - 0,5 мг / мл, аспирин 30 мг / л & & 36 \\
\hline 14. & Биогенные амины & & 32 \\
\hline
\end{tabular}

состав вина: вода - 86\%, этанол - 12\%, глицерин - 1\%; органические кислоты - 0,4\%, полифенольные соединения и таннины - 0,1\%, другие соединения - 0,5\%. Более подробный состав приведен в табл. 2.

Всего в мире известно более 10 тыс. сортов винограда. Ежегодного выращивают и снимают урожай в объеме 75 млн т, 70\% перерабатывают в вино, 27\% употребляют в свежем виде, 2\% сушат. При производстве вина образуется 9 млн т отходов, которые содержат полезные полифенольные соединения, поэтому в последние годы создаются разные технологии утилизации. Вино хранят в дубовых бочках, используются дубы возрастом до 170 лет из Франции, Италии, США. Пробки для стеклянных бутылок изготавливают из пробкового дерева из Португалии (52\%), Испании (29\%) и Италии. Потребление вина растет в Китае, Бразилии, Аргентине, Египте. Самые полезные соединения красного вина полифенолыантиоксиданты: флавоноиды, фенольные кислоты, стильбены, лигнаны и др. Особенно ценны: ресвератрол, мелатонин, гидрокситирозол, аспирин, витамины. В отличие от белого вина, при производстве красного используется кожица и зерна винограда, поэтому в нем содержится полифенолов 
Таблица 3. Содержание проантоцианидинов в винах

\begin{tabular}{|c|c|c|c|c|c|c|c|}
\hline \multirow[t]{2}{*}{ Напитки } & \multicolumn{7}{|c|}{ Проантоцианидины, мг/100 г } \\
\hline & мономеры & димеры & тримеры & 4-6-меры & 7-10-меры & полимеры & сумма \\
\hline Красное вино & 16,64 & 20,49 & 1,8 & 6,7 & 5 & 11 & 61,63 \\
\hline Розовое вино & 1,33 & 0,86 & 0,01 & - & - & - & 2,20 \\
\hline Белое вино & 0,59 & 0,21 & 0,01 & - & - & - & 0,81 \\
\hline
\end{tabular}

в 10 раз больше. Флавонолов в белом вине практически нет [41].

Цвет вина зависит от сорта винограда и времени выдержки. Фиолетовый оттенок имеет молодое вино, кирпично-красный - вино средней выдержки, коричневый цвет - старое вино.

Содержание антоцианинов и проантоцианидинов в красных винах также значительно выше, чем в белых винах (табл. 3) (USDA Database for the flavonoid content of selected Foods 2003).

В красных винах методом хроматографии - массспектрометрии идентифицировано более 100 полифенольных соединений, включая флавоноиды и полифенолы нефлавоноидной природы [42]. Высокое содержание полифенольных соединений в красных винах связывают с тем, что в процесс ферментации виноградного сока включается кожица ягод и зерна винограда. Кожица винограда особенно богата полифенольными соединениями. Многие полифенолы водорастворимы, другие же экстрагируются только водно-спиртовыми смесями. В последние годы израильскими виноделами показано, что при включении в процесс брожения белого вина кожицы винограда и зерен, антиоксидантная активность его возрастает в несколько раз [43].

В работе [44] определено общее содержание полифенолов в некоторых итальянских красных и белых винах (всего 13 видов). Суммарное содержание полифенолов в красных и белых винах колебалось в пределах 1365-3326 и 146-96 мг / л соответственно, флаванолов 203-805 и 11-49 мг / л соответственно. Флавонолов в красных винах содержится около 15 мг / мл (в основном, кверцетин и рутин, за которыми следовали мирицетин, кемпферол и изохамнетин), в белых винах флавонолов не обнаружено.

\section{Из истории вина}

Вино-наш друг, но в нем живет коварство: Пьешь много - яд, немного пьешь-лекарство. Не причиняй себе излишнего вреда Пей в меру - и продиится жизни царство. Абу-ибн-Сина (Авищенна)

"История вина неотделима от истории человечества Вино - плод винограда и человеческого труда, не должно восприниматься как просто напиток. Тысячелетиями сопровождающее человека, оно всегда имеет две ипостаси: священную и вульгарную. Оно и мерило цивилизации, и критерий качества жизни. Оно - достояниекультуры и фактор общественной жизни» (Официальное коммюнике французской делегации на заседании Европейской комиссии в Брюсселе в 1990 году).

Вино прошло длительный путь от эликсира бессмертия в Древней Греции, став напитком удовольствия

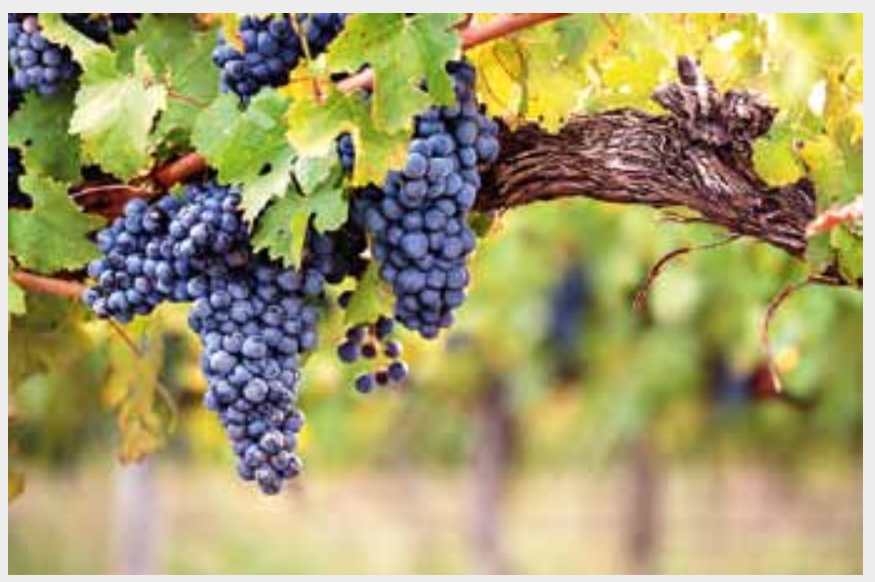

и дружеского расположения, до особого символа в таинстве причастия в христианской литургии. Вино было напитком богов, прежде чем его вкусили люди. Считается, что впервые вино появилось в Грузии и Иране 6000 лет до н. э., затем в Индии и Египте, а позднее 
Содержание свободных и конъюгированных мирицетина и кверцетина в красных винах различного географического происхождения было определено в работе [25]. Методом ВЭЖХ исследовано 65 красных вин из винограда "Каберне Совиньон" производства Италии, Чили, Франции, Калифорнии, Австралии, Болгарии, Марокко и Венгрии. Суммарное содержание флавонолов в этих винах колебалось в пределах 4,6-41,6 мг/л.

По мнению авторов, это различие связано с толщиной кожицы винограда сорта "Каберне Совиньон". В свою очередь соотношение объема ягоды и толщины кожицы определяется полнотой созревания и количеством солнечных дней перед сбором урожая. Кроме того, концентрация флавоноидов зависит от применяемой технологии виноделия. Самое высокое содержание флавонолов в винах производства Чили (41,6 мг/л), а самое низкое - у болгарских (менее 6 мг/л). Ради справедливости следует отметить, что исследуемые болгарские вина были производства 1989 и 1990 годов, а содержание антиоксидантов со временем падает.

В работе [45] приведена классификация немецких красных вин (52 типа) по содержанию в них антоцианов (антоцианидинов и антоцианинов), измеренных методом ВЭЖХ.

Цвет красных вин определяется моно- и диглюкозидамиантоцианинов пяти исходных антоцанидинов: делфинидина, цианидина, петунидина, пеонидина и малвидина. Подделка вин по цвету осуществляется двумя способами: добавлением соков разных ягод и разбавлением другим более глубоко окрашенным вином (но не более 15\%). Первый способ подделки легко определяется методом ВЭЖХ.

В работе [42] методом ВЭЖХ и ВЭЖХ-МС определено 16 антоцианинов в красных винах также с целью их классификации. Антоцианины определяли при длине волны 520 нм, чувствительность определения на уровне 0,18 ppm. Методом ВЭЖХ-МС идентифицировано 44 пигмента. Пурпурнокрасный цвет молодого красного вина связан с антоцианинами, которые экстрагируются, в основном, из кожицы черного винограда.

В процессе старения вина антоцианины реагируют с другими компонентами красного вина, в результате чего получаются более стабильные природные пигменты кирпично-красного цвета.

В [46, 47] показано, что амперометрический способ дает лучшие результаты при определении суммарного содержания антиоксидантов красного вина по сравнению с другими методами.

Мы провели измерения суммарного содержания антиоксидантов (ССА) более чем в 80 образцах красных вин, взятых непосредственно у производителей на выставках элитных вин в Гостином Дворе и "Интердринк", а также приобретенных в московских магазинах. Среди исследуемых были образцы распространилось среди стран Средиземноморского региона. Миф Египта гласит, что бог Солнца Ра передалвино в дар Земле. В Греции богом вина был сын Зевса Дионис, празднование в честь которого проводилось весной. В идеальном городе Платона люди будут производить зерно и вино, радоваться своим детям, наслаждаться вином. У древних римлян богом вина был Вакх. Ной после потопа, прежде всего, посадил виноград и два других священных библейских растения - оливковое и фиговое деревья. Бог наказал свой избранный еврейский народ, разрушив виноградники, а когда пришел день прощения - вернул их. Вино как символ крови появилось еще в Ветхом завете. В Песне песней - вино знак единения мужчины и женщины. Благодаря своим достоинствам вино упоминается в библии 450 раз. Апостол Павел советует Тимофею полечить язву желудка вином, а Вавилонский талмуд признает его эффективным лечебным средством. Однако в Библии есть предупреждение об опасности злоупотребления этим напитком. Из семи смертных грехов есть пьянство. В Новом завете Иисус сотворил свое первое чудо, превращая на свадьбе воду в вино. Во время Тайной вечери, совместной трапезы (греч.евхаристии) Иисуса и его учеников мистика вина обретает особое значение. Иисус поднимает кубок с вином и говорит «Сие есть кровь моя, когда будете пить вино, делайте это в память обо мне». Поэтому вино в христианской традиции не только источник радости, мира, но и прежде всего символ священной связи человека и божественной сущности. Принято считать, что исламская религия запрещает пить вино. Однако в Коране нет прямого запрета, хотя отмечен вред чрезмерного употребления вина. Одна из сур Корана гласит: "Ешьте и пейте, но не превышайте меру». Сунниты-фундаменталисты запретили пить вино. Раскольники-шииты позволяют употребление вина в умеренных количествах. В девятом веке виноградарство процветало в мусульманских странах. Врач Авиценна говорил: «Вино - друг мудрого и враг пьяницы. И потому религия позволяет пить вино 
вин из Чили, Франции, Италии, Аргентины, ЮАР, Македонии, Румынии, Австрии, Греции, России, Украины, Грузии и Молдавии. Исследования показали, что суммарное содержание антиоксидантов хороших натуральных красных вин (относительно стандарта кверцетина) колеблется от 250 до 100 мг на 100 мл (табл. 4).

Содержание антиоксидантов в некоторых молдавских и грузинских винах, приобретенных в магазинах, было значительно (в пять раз) ниже приведенных величин, что, по нашему мнению, может указывать на их фальсификацию.

Таким образом, измерение содержания антиоксидантов может дать дополнительную информацию не только о качестве и пользе красного вина, но и о его подлинности.

\section{Определение ресвератрола в винах}

Количество ресвератрола в винограде зависит от сорта винограда, почвы, погоды, степени грибкового поражения, загрязнений окружающей среды, технологии переработки и хранения.

В винограде ресвератрол синтезируется в основном в кожице, ниже его содержание в косточках (в 5-7 раз) и еще меньше - в мякоти (в 10-50 раз).

Было показано, что в соке красного винограда содержание транс-ресвератрола колеблется в пределах 0,01-1,1 ppm, а цис-ресвератрола - в пределах 0,003-0,23 ppm. В белом вине обнаружен
Табпица 4. Суммарное содержание антиоксидантов (ССА) в красных винах

\begin{tabular}{|c|c|c|}
\hline $\begin{array}{l}\text { Страна } \\
\text { происхождения }\end{array}$ & $\begin{array}{c}\text { Число } \\
\text { исследуемых } \\
\text { образцов }\end{array}$ & $\begin{array}{c}\text { ССА, } \\
\mathrm{мг/100мл}\end{array}$ \\
\hline Франция & 7 & $110-240$ \\
\hline Чили & 5 & $115-215$ \\
\hline ЮАР & 3 & $130-185$ \\
\hline Аргентина & 2 & 150,155 \\
\hline Македония & 4 & $115-175$ \\
\hline Румыния & 2 & 111,185 \\
\hline Австрия & 1 & 120 \\
\hline Украина & 2 & 105,110 \\
\hline Грузия & 12 & $40-160$ \\
\hline Молдавия & 6 & $20-160$ \\
\hline
\end{tabular}

транс-ресвератрол в количестве 0,05 ppm, а цисресвератрол полностью отсутствовал. В красных винах в среднем около 3,15 ppm транс-ресвератрола и 1,84 ppm цис-ресвератрола, в розовых винах содержится промежуточное количество этих веществ.

Интерес к ресвератролу в первую очередь связан с его высокой антиоксидантной активностью, а также с антиканцерогенным, мудрому, а разум запрещает это глупому». В двенадцатом веке опубликовано прекрасное поэтическое произведение - «Похвала вину» Омара Хайяма. Фараон в Египте и его сановники пили вино. В Греции трапезы с вином называли "симпозиумом", что означало буквально пить вино. Греки делали ароматизированные вина с медом, тимьяном, мятой, корицей. Теофраст-ученик Гиппократа (312-287 до н. э.) также создавал лечебные вина, добавляя в них травы и пряности, обладавшие фитотерапевтическими свойствами. В античной Греции вино широко применяли для лечения, использовали для обработки ран во время осады Трои. В «Иллиаде» и «Одиссее» вино льется рекой. Гиппократ писал: “Вино удивительно соответствует человеку как в здоровье, так и в хворях. Его предписывают по необходимости и в определенных количествах в соответствии с индивидуальным телосложением». Он советовал пить вино: "Оно заставляет смеяться и создает хорошее настроение, а суровый нрав и грустное настроение - причины болезней». В Риме считали, что вино дано людям Сатурном - богом посевов и виноделия. Римляне выдерживали вино десятилетиями. Поэты Апиций, Гораций, Плиний, Марциал описывали восхитительные вина. В Риме пить вино имели право только мужчины после тридцати лет. Запрет на вино женщинам действовал долго. Римский врач Гален (130-201 до н.э.) утверждал, что вылечил нарушение пищеварения у императора Марка Аврелия: «я прописал ему стакан вина, приправленного перцем».

Первые виноградники во Франции (Галлии) появились около 600 г до н. э. Современники Юлия Цезаря меняли раба на амфору вина. Большим поклонником вина был Ф. Рабле, а его современник М. Монтень был не только литератором, но и виноделом.Голландский гуманист Э. Ротердамский использовал вино для активизации пищеварения, Мольер также считал вино терапевтическим средством, а врач Гельвеций им лечил короля 
кардиопротекторным, антивирусным, противовоспалительным и противоагрегационным действиями. Считалось, что "французский парадокс»" объясняется в первую очередь именно присутствием транс-ресвератролов в винах. Сегодня пользу от употребления красного вина связывают также с содержанием в нем других природных полифенолов.

Ранее были проведены исследования на жидкостном хроматографе "МаэстровЭЖХ" с амперометрическим детектором на колонке $150 \times 0,4$ см с сорбентом $\mathrm{C}_{18}$ с элюентом ацетонитрил-вода. Предварительно выбрали оптимальные условия разделения и количественного определения транс- и цисресвератролов (рис. 1) [48]. Амперометрический детектор позволяет определять ресвератролы на уровне $10^{-10}-10^{-9}$ г за счет

* Высокая продолжительность жизни французов, употребляющих красное вино. - Прим.ред.

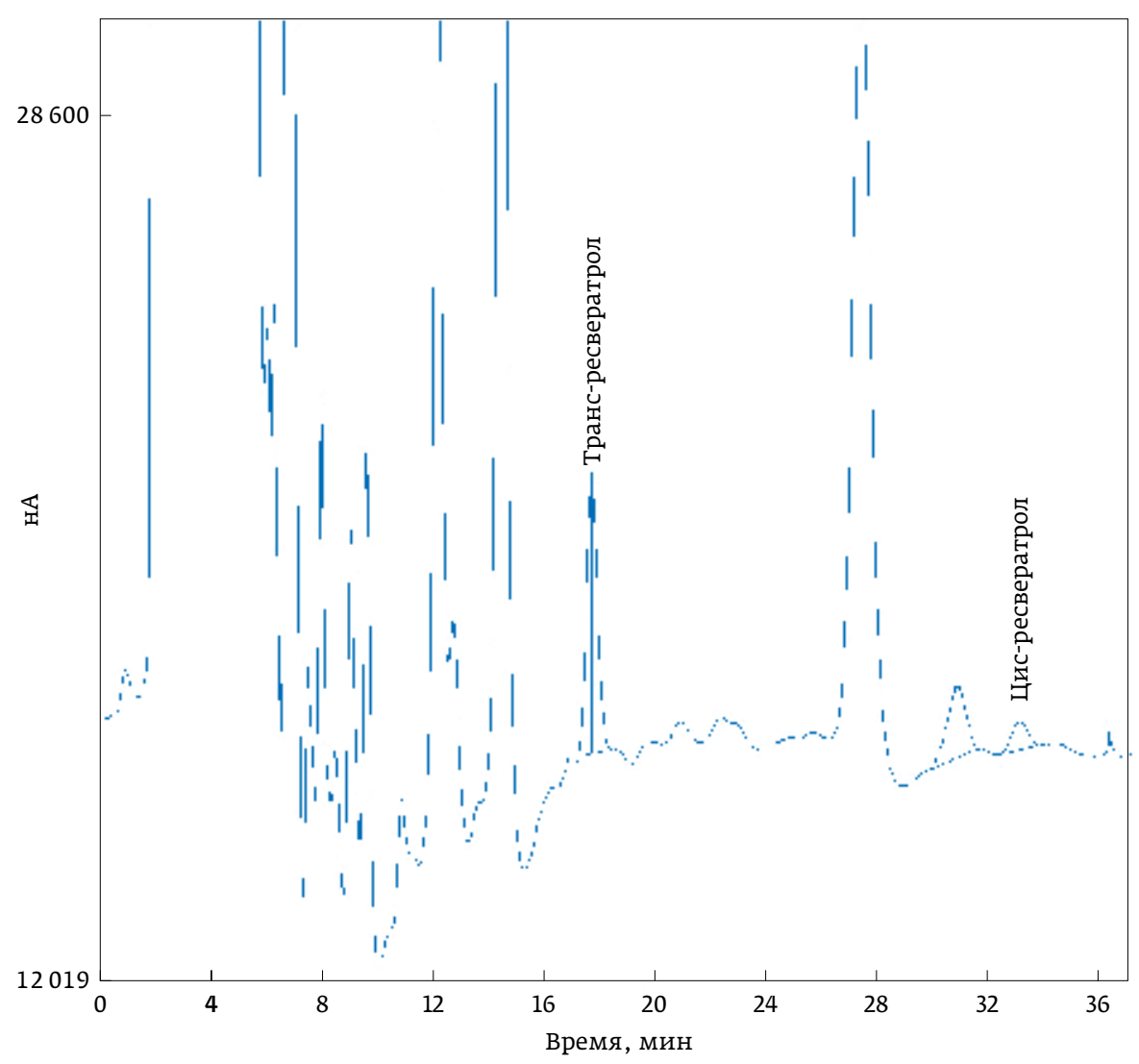

Puc. 1. Транс- и цис-ресвератролы в сухом красном вине (разбавление в 10 раз). Условия: сорбент Кромасии С18 2×250 мм 5 мкм, элюент 25\% ащетонитрии, 20 мM К ${ }_{2} \mathrm{HPO}_{4} ;$ pH 2,8 (ортофосфорная к-та), петля 20 мки, расход эиюента 0,3 мл/ мин
Людовика XIV. По мнению Вольтера: “В умеренных количествах вино служит лекарством для души и тела». В «Энциклопедии» Дидро вину посвящена большая статья. Красное вино возведено в ранг напитка равноправия во время революции во Франции, а белое вино сброшено с пьедестала, так как цвет его ассоциировался с королевским флагом. Александр Гримо де Ла Реньера в "Альманахе гурмана» в 1803 году писал, что, по мнению многих любителей, "вино - лучший друг человека, если его пить умеренно, и самый большой враг, если им злоупотреблять. Оно - ваш спутник в жизни, утешитель в печалях, главный источник подлинных чувств. Вино молоко престарелых, бальзам взрослых и колесница гурманов". Луи Пастер писал, что вино - самый здоровый и гигиеничный напиток.

В книгах Салернской медицинской школы (Италия, Кампанья) записано: "Доброе вино позволяет старикам пережить вторую молодость. Чистое вино обладает многими достоинствами: оно повышает тонус, доставляет удовольствие желудку, гонит плохое настроение. Вино придает живость уму, блеск взору, тонкость слуху, избавляет от тучности и дарит крепкое здоровье».

В 1840 году парижская фармакопея содержала 164 названий лечебных вин. Врачи Франции рекомендовали вино для борьбы с дизентерией и холерой. В 1934 году Национальный конгресс врачей предложил "Кодекс энотерапии", появились книги: "Мой доктор вино", "Лечитесь вином", "Терапия вином», "Вино лекарь».

В наше время о лучших качествах вина, его истории, технологиях приготовления, химическом составе, влиянию на здоровье человека и др. написаны десятки книг [1-15]

Самые крупные производители виноградных вин: Франция, Италия, Испания, Чили, США, Аргентина, Португалия, Южная Африка, Австралия, Германия. 
присутствующих в их молекулах трех гидроксильных групп (рис. 2).

Определены ресвератролы в 30 образцах вин из разных стран (Чили, Южная Африка, Италия, Россия и др.) и разных сортов винограда (Каберне, Каберне-Совиньон, Шардоне, Мерло и др.). Некоторые результаты анализов приведены в табл. 5 . Во всех образцах вин кроме транс-ресвератрола, содержится и цис-ресвератрол. Даже в стандартном образце транс-ресвератрола фирмы "Флука" присутствовал и цис-ресвератрол.

Содержание ресвератролов в исследованных образцах красных вин колеблется в пределах 0,05-2,6 мг/л, что соответствует опубликованным данным.

Полученные результаты позволяют выбирать красные вина с повышенным содержанием ресвератролов для профилактического лечения в антиоксидантной терапии.

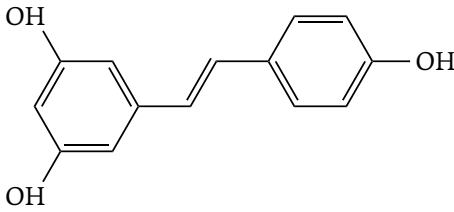

a)

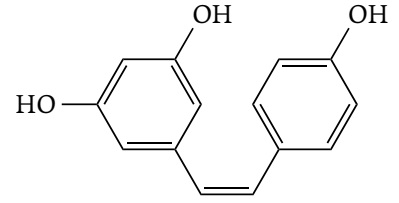

б)
Puc. 2. Структурные формулы: $а$ - транс- и б-цис-ресвератрола

\section{Антиоксидантная активность красных вин}

Антиоксидантная активность (АА) напитков и пищевых продуктов - важный показатель для антиоксидантной терапии окислительного (оксидантного) стресса и сопутствующих ему болезней. Окислительный стресс - это состояние организма с избыточным содержанием свободных радикалов и реакционных кислородных и азотных соединений.

Табпица 5. Содержание транс- и цис-ресвератролов в сухих красных, розовых и белых винах

\begin{tabular}{|c|c|c|c|c|}
\hline & \multirow[t]{2}{*}{ Название вина, сорт винограда, год выпуска, страна производитель } & \multicolumn{3}{|c|}{ Содержание ресвератролов, мг/л } \\
\hline & & Транс- & Цис- & Сумма \\
\hline 1 & Вино красное "ExposicionCarmenere», 2005, (Чили) & 1,80 & 1,20 & 3,00 \\
\hline 2 & Красное вино "Эстампа Каберне Совиньон", 2006, (Чили) & 2,00 & 0,60 & 2,60 \\
\hline 3 & Красное вино "Эстампа Каберне Совиньон Мерло», 2006, (Чили) & 1,60 & 0,80 & 2,40 \\
\hline 4 & Красное вино «НегроамароСаленто ИГТ», 2006. (Италия, Апулия) & 0,80 & 1,20 & 2,00 \\
\hline 5 & Вино красное «Мерло Мысхако», 2006, (Россия) & 0,50 & 1,40 & 1,90 \\
\hline 6 & Красное вино "Саленто ИГТ», 2006, (Италия, Апулия) & 0,40 & 0,80 & 1,20 \\
\hline 7 & Красное вино "Вистамар Каберне Совиньон», 2006, (Чили) & 0,80 & 0,20 & 1,00 \\
\hline 8 & Вино красное "Каберне Мысхако", 2005, (Россия) & 0,20 & 0,40 & 0,60 \\
\hline 9 & Красное вино “Нерод, АволаСанджовезеЭмпорио», 2004, (Италия, Сицилия) & 0,50 & 0,10 & 0,60 \\
\hline 10 & Красное вино "LasMorasMalbec», 2006, (Аргентина) & 0,25 & 0,35 & 0,60 \\
\hline 11 & Вино красное «Мерло Тамани», 2006, (Россия) & 0,40 & 0,10 & 0,50 \\
\hline 12 & Вино красное "Каберне Тамани", 2006, (Россия) & 0,40 & 0,10 & 0,50 \\
\hline 13 & Красное полусухое “Каберне Совиньон”, 2006, (Южная Африка) & 0,30 & 0,20 & 0,50 \\
\hline 14 & Красное вино "Кьянти Badiolo", (Италия) & 0,30 & 0,10 & 0,40 \\
\hline 15 & Белое вино «Эстампа Шардоне», 2006, (Чили) & 0,35 & 0,05 & 0,40 \\
\hline 16 & Красное вино "LasMorasBonarda», 2006, (Аргентина) & 0,09 & 0,15 & 0,24 \\
\hline 17 & Вино белое "Шардоне Мысхако", 2007, (Россия) & 0,12 & 0,07 & 0,19 \\
\hline 18 & Вино белое "Совиньо Блан Мысхако", 2007, (Россия) & 0,09 & 0,02 & 0,11 \\
\hline 19 & Розовое вино "FolonariBardolinoChiaretto", 2005, (Италия) & 0,05 & 0,06 & 0,11 \\
\hline 20 & Белое вино “Мальвазия ШардонеСаленто ИГТ», 2006, (Италия, Апулия) & 0,10 & 0,01 & 0,11 \\
\hline 21 & Белое вино «Шардоне Сицилия ИГТ", 2005/2006 (Италия, Сицилия) & 0,05 & 0,01 & 0,06 \\
\hline
\end{tabular}




\section{КЛЮЧЕВОЕ СОБЫТИЕ ОТРАСЛИ:}

в центре внимания, в центре Москвы

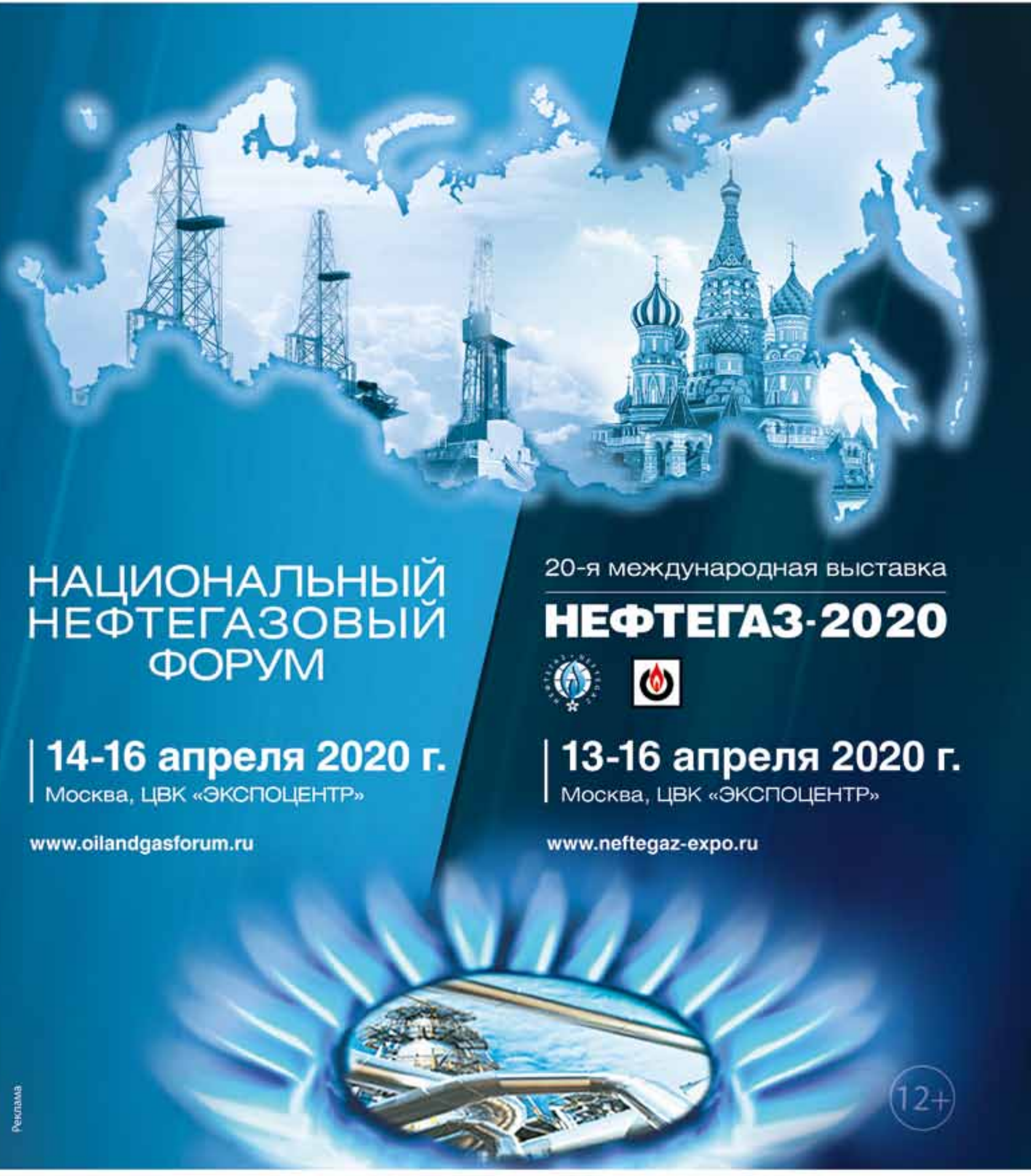

y

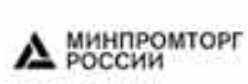

क्ष

श्वाiा

Monctioños

$\Theta$

VDMA

औ

TIT $\because n$ 
Свободные радикалы играют положительную роль в уничтожении инородных тел, попадающих в организм. В здоровом организме имеется трехуровневая естественная система антиоксидантной защиты человека, включающая низкомолекулярные эндогенные (цистеин, глутатион восстановленный, липоевая кислота, убихинол и др.), среднемолекулярные и высокомолекулярные ферменты. Однако при воздействии неблагоприятных факторов (сильное облучение, эмоциональный стресс, загрязнители пищевых продуктов и окружающей среды, курение, наркомания и др.) естественная система защиты не справляется, и избыточное содержание свободных радикалов приводит к окислению жизненноважных молекул (ДНК, белков, жиров) и клеточных мембран. Окисление молекул ДНК может привести к онкологическим болезням, окисление липопротеинов низкой плотности ускоряет развитие атеросклероза. Окисление клеточных мембран нарушает многие обменные процессы, что может вызвать разные болезни. Сегодня установлена прямая связь окислительного стресса с более 100 болезнями и преждевременным старением, поэтому важно его диагностировать на ранней стадии и подавить терапией лекарствами-антиоксидантами, пищевыми продуктами и напитками с АA.

На сегодняшний день опубликованы десятки работ по определению АА вин [49-67]. Основные способы определения: классические методы DPPH, ABTS, FRAP, ORAC [44,47], хемилюминесцентный [50], ВЭЖХ [54, 61], спектрофотометрические [54, 56], пульсирующая вольтамперометрия [54], флуориметрический [55], амперометрический [46, 47, 58], кулонометрический $[62,64]$. Исследована АА отдельных полифенолов вин: антоцианинов $[57,59]$, катехинов, процианидинов и пироантоцианидинов [57], фенолокислот [60]. Установлена пропорциональная связь АА вин с суммарным содержанием полифенолов [51]. Ранее считали, что антиоксидантная активность красного вина определяется содержанием трансресвератрола (транс-3,5,4-тригидроксистильбен). Однако методом ВЭЖХ было установлено, что основной вклад в АА красного вина вносят флавоноиды: катехин, эпикатехин, рутин, кверцетин, мирицетин и др. (табл. 6).

Содержание полифенолов в красном вине значительно выше, чем в белых винах, в некоторых случаях в десять и более раз. Среднее значение АА (относительно тролокса как стандарта) для красных вин - 12,3 Мм, для белых вин - 1,6 Мм. В работе [65] проведено сравнение АА вин из Бордо (5 типов красного и 4 типа белого вина) по Фолин методу. Среднее значение АА красных вин 6738 Мм, белых вин 511 мМ,
Табпица 6. Содержание фенольных компонентов в красном и белом винах

\begin{tabular}{lcc}
\hline Название полифенолов & $\begin{array}{c}\text { Красное вино, } \\
\text { мг/л }\end{array}$ & $\begin{array}{c}\text { Белое вино, } \\
\text { мг/л }\end{array}$ \\
\hline Катехин & 191 & 35 \\
\hline Эпикатехин & 82 & 21 \\
\hdashline Галловая кислота & 95 & 7 \\
\hdashline Цианидин & 3 & 0 \\
\hdashline Малвидин-З-глюкозид & 24 & 1 \\
\hdashline Рутин & 8 & 0 \\
\hdashline Мирицетин & 9 & 0 \\
\hdashline Кофейная кислота & 7,1 & 2,8 \\
\hline Ресвератрол & 1,5 & 0 \\
\hline
\end{tabular}

то есть в 14 раз ниже. Антиоксидантная эффективность вин относительно катехина изучена тремя разными методами [66]. Средняя АА красных вин также оказалась в 10 раз выше, чем белых. Антиоксиданты вносят значительный вклад в общую АА красного вина [64]. В работе [58] показано, что амперометрический способ показывает лучшие результаты при определении суммарного содержания антиоксидантов красного вина по сравнению с другими методами.

В фундаментальной работе [62] кулонометрическим методом оценена АА многих вин из разных стран: Чили, Франции, Италии, Аргентины, ЮАР, Австралии, Испании, Болгарии, Венгрии, Румынии, Грузии, Молдовы, Армении, Украины, Азербайджана. АА хереса из Массандры и мадеры крымской было ниже АА красных вин. Высокие значения АА у австралийских вин "Каберне-Мерло" и "Каберне-Совиньон", у испанского вина "Кармен", у итальянского "Кьянти классическое". Известны работы по определению АА красных вин из разных континентов мира, стран и регионов: Франция [74], Италия [75], Испания [79], Португалия [76], Сербия [81], Хорватия [78], Черногория [86], Польша [82], Словакия и Австрия [80], Чехия [84], Греция [70], Турция [69], Грузия [68], Индия [71], Китай [83], Чили [72], Аргентина [77], Бразилия [85], Южная Африка [73] и Краснодарский край РФ [87].

Невиноградные вина. Кроме винограда для производства вина используют лекарственные растения, ягоды и фрукты [88-98]. Описаны свойства вин из бузины [88], шелковицы [90], крушины [98], граната [94], яблочно-чайные [95]. Так называемые гербальные вина $[91,93]$ изготавливают из 
лекарственных трав, имбиря, алое, базилика, чеснока, диких ягод. Фруктовые вина [89, 92] производят из яблок, вишни, сливы, граната, черной малины, киви, манго и др. В красные вина добавляют экстракты зерен винограда с большим содержанием катехинов. Красное вино выдерживают не только в дубовых бочках, но и в бочках из акации, вишни, шелковицы.

\section{Влияние умеренного потребления красного вина на здоровье человека}

Красное вино потреблялось человеком на протяжении нескольких тысячелетий, это самый древний напиток. На протяжении всей истории человечества самые известные врачи древности, философы, поэты отмечали пользу вина для здоровья человека. В наше время лечебные свойства вина заинтересовали серьезных ученых. К этому подтолкнуло явление "французского парадокса" в девяностые годы прошлого века. Более тридцати лет назад в США ежегодно регистрировалось около 800 тыс. внезапных смертей 40-65-летних мужчин от сердечнососудистых заболеваний. Для борьбы с этим злом была принята специальная программа и выработаны рекомендации для групп риска: не употреблять жирную пищу, не курить, увеличить физическую активность и пр. В США стали все бегать, даже президенты, курение под запретом (более 70\% мужчин не курят). В течение 30 лет благодаря действию этой программы число смертей сократилось вдвое, но дальше не уменьшалось. Медики США стали изучать, как обстоят дела в других странах и обратили внимание, что во Франции смертность от сердечно-сосудистых заболеваний в два раза ниже, чем в США, хотя французы едят жирную пищу и больше курят. Этот парадокс связали с регулярным потреблением французами красного вина, в котором содержится много природных антиоксидантов, полезных для работы сердца.

В последние годы опубликованы десятки обзоров о благоприятном влиянии умеренного потребления красного вина на здоровье человека $[4,11$, 12-15, 99-111], особенно профилактике сердечнососудистых болезней [112-119]. Красное вино способствует нормализации давления [120] и уменьшает окисление липопротеинов низкой плотности [121]. Умеренное потребление красного вина снижает риск онкологических заболеваний [123-127], диабета второго типа [128] и нейродегенеративных (Альцгеймера и Паркинсона) недугов $[130,131]$. Перечень других болезней, риск которых уменьшается при потреблении красного вина, приведен в табл. 7.
Таблица 7. Влияние регулярного потребления красного вина на здоровье человека

\begin{tabular}{|c|c|}
\hline Название болезней & Ссылки \\
\hline Общие обзоры: красное вино и здоровье & $99-111$ \\
\hline Сердечно-сосудистые заболевания & $112-119,122$ \\
\hline Гипертония & 120 \\
\hline $\begin{array}{l}\text { Окисление липопротеинов низкой } \\
\text { плотности }\end{array}$ & 121 \\
\hline Онкологические заболевания & $123-127$ \\
\hline Диабет второго типа & 128 \\
\hline $\begin{array}{l}\text { Нейродегенеративные болезни: } \\
\text { Альцгеймера и Паркинсона }\end{array}$ & 130,131 \\
\hline Воспалительные процессы & 135 \\
\hline Болезни почек & 129 \\
\hline Окислительный стресс & $132-134$ \\
\hline $\begin{array}{l}\text { Подавление бактерий хеликобактер } \\
\text { пилори }\end{array}$ & 141 \\
\hline Болезни полости рта & 136 \\
\hline Аллергические болезни & 142 \\
\hline Дисбактериоз & $137,133,143$ \\
\hline Депрессии & 143 \\
\hline Рассеянный склероз & 138 \\
\hline Хронические болезни & 145 \\
\hline
\end{tabular}

В США установили безопасную норму потребления красного вина: для женщин 150 мл, для мужчин 300 мл в день (12 и 24 г этанола, соответственно). Больным, которым запрещено употребление алкоголя, рекомендованы безалкогольные экстракты из вина, кожицы и зерен красного винограда. Кроме того, производятся безалкогольные и низкоалкогольные вина [146].

\section{Заключение}

Тысячелетняя история красного вина убедительно доказывает пользу его умеренного потребления. Многочисленные научные исследования последних десятилетий также подтвердили оздоровительное действие красного вина и показали возможность профилактического использования для предотвращения самых опасных социально-значимых заболеваний: сердечно-сосудистых, онкологических, нейродегенеративных, диабета второго типа и др. Красное вино подавляет окислительный стресс - предшественник многих болезней, поэтому может быть компонентом 
комплексной антиоксидантной терапии. Красное вино улучшает микробиоту кишечника, что непосредственно влияет на здоровье. И все это благодаря содержанию широкого ассортимента полезных соединений: полифенолов-антиоксидантов, витаминов и микроэлементов. Разнообразными аналитическими методами установлена высокая антиоксидантная активность, по которой красное вино превосходит все остальные напитки: флавоноиды, фенольные кислоты, стильбены, лигнаны, проантоцианидины. Особенно следует выделить ресвератрол, кверцетин, дигидрокситирозол, мелатонин и аспирин. Сотни новых полифенольных соединений идентифицировано в красном вине методами хроматографии-масс-спектрометрии высокого разрешения.

В нашей стране Ассоциацией специалистов восстановительной медицины (АСВОМЕД) разработана комплексная программа энотерапии (лечение вином), которую планируется предложить центрам здоровья, домам отдыха, пансионатам, санаториям, спа-салонам. Специалисты ассоциации подобрали коллекцию из 20 сортов вина для программы антистарения и активного долголетия. Экстракт красного вина без этанола, в частности эноант (Магарач, Ялта), также можно использовать в энотерапии и включать в функциональное лечебное питание.

В настоящий момент в Государственной думе готовится закон о вине, который должен стать гарантией производства качественных натуральных виноградных вин. Нельзя отрицать важность вина и как пищевого продукта (все дело в культуре потребления!), с одной стороны, и большое значение экономически выгодной отрасли - производства вина, с другой стороны.

\section{Литература / References}

1. Morreno-Arribas M.V., Polo M.C. Wine chemistry and biochemistry. New York. Springer. 2009.

2. Morata A. Red wine technology. Academic Press. 2018. 408 p.

3. Annino E. Book review- Wine reads. A literary anthology of wine writing. Editied by J. Melnerney. 2019.

4. O-Bqrne P. (Ed). Red wine and health. Nova science publishers. Inc. 2009.

5. The science of red wine. Flavor, texture and tannins. J. Kennedy. 2007. Update.

6. Jackson R.S. Wine science-Principles and application. 3-nd. Edit. Elsevier. Academic Press. Amsterdam. 2008.

7. Clarke R.J., Bakker J. Wine flavor chemistry. Blackwell Publishing. Ltd. Oxford. 2004.

8. Lukas P. Inventing wine-A new history of one of the world's most ancient pleasures. WW Norton and Company. New York. USA. 2012.

9. Кишковский 3.Н. Химия вина. Москва. Пищевая промышленность. 1976. 311 с.
Kishkovskij Z.N. WineChemistry. Moscow. Pishhevaja promyshlennost' Publ., 1976, $311 \mathrm{p}$.

10. Валуйко Г.Г. Биохимия и технология красных вин. Москва. Пищеваяпромышленность. 1973. 296 с.

Valujko G. G. Biochemistry and Red Wine Technology. Moscow. Pishhevajapromyshlennost' Publ., 1973, 296 p.

11. Ингельхайм Ф.А. Преображенский В. Пейте на здоровьеЛечение вином. ФАИР. 2002. Ingel'hajm F. A., Preobrazhenskij V. Drink on health - Wine treatment. FAIRPubl., 2002.

12. Починюк О.Н. Красное и белое вино для вашего здоровья. Ростов-на-Дону. Феникс. 2006.

Pochinjuk O.N. Red and White Wine For Your Health. Rostov-onDon. FeniksPubl., 2006.

13. Нужный В.П. Вино в жизни и жизнь в вине (вино и мы). Изд-во НПО "Моден". Москва - Воронеж. 2000. 352 с. Nuzhnyj V.P. Wine in Lives and Life in Wine (Wine and We). Moscow - Voronezh, NPO "Moden" Publ., 2000, 352 p.

14. Монтиньяк М. Чудесные свойства вин.Как пить вино, чтобы укрепить здоровье. Москва. ОНИКС.1999. 235 с.

Montin'jak M. Wonderful Wine Properties. How to Drink Wine to Strengthen Health. Moscow. ONIKSPubl., 1999, 235 p.

15. Шалыгин Л.Д. Вино в восстановительной медицине и медицинской реабилитации. Издательство: Асвомед. 2007. 255 c.

Shalygin L.D. Wine in Restorative Medicine and Medical Rehabilitation. AswomedPubl., 2007, 255 p.

16. Захарова А., Кравченко А., Иванова А., Исупова Н., Гринштейн И. Сравнительный анализ красного вина методом ВЭЖХ и атомно-эмиссионной спектроскопии // АНАЛИТИКА. 2017. № 2. C. 86-96.

Zaharova A., Kravchenko A., Ivanova A., Isupova N., Grinshtein I. A Comparative Analysis of Red Dry Wine by Methods of High-Performance Liquid Chromatography and Atomic Emission Spectroscopy. Analitika-Analytics, 2017, no. 2, pp. 86-96.

17. Колеснов А.Ю., Филатова И.А., Задорожная Д.Г., Малошницкая О.А. Масс-спектрометрия стабильных изотопов $\mathrm{O}_{18} / \mathrm{O}_{16}$ в винодельческой продукции для установления ее подлинности // Виноделие и виноградарство. 2012. № 6. C. 10-15.

Kolesnov A.Ju., Filatova I.A., Zadorozhnaja D.G.,

Maloshnickaia O. A. Mass Spectrometry of Stable Isotopes O18/O16 in Wine Production to Establish its Authenticity. Vinodeliei vinogradarstvo -Winemaking and Wine Growing,2012, no. 6, pp. 10-15.

18. Сарварова Н.Н., Марченко И. А., Ризванов И.Х., Токмин Д.Г. Определение содержания полиолов методом ГХ-МС без экстракции для оценки качества столовых вин // Виноделие и виноградарство. 2012. № 6. С. 16-20.

Sarvarova N.N., Marchenko I.A., Rizvanov I.H., Tokmin D.G. Determination of PolyolContent by CC-MS Without Extraction to Assess Table Wine Quality.Vinodelie i vinogradarstvo-Winemaking and Wine Growing, 2012, no. 6, pp. 16-20.

19. Селиверстова И.В., Иванов А. А., Иванова А. А. Определение органических кислот в вине методом жидкостной ионоэксклюзионной хроматографии // Виноделие и виноградарство. 2001. № 4. C. 9-11.

Seliverstova I.V., Ivanov A.A., Ivanova A. A. Determination of Organic Acids in Wine by Liquid Ion - Exclusion Chromatography. Vinodelie i vinogradarstvo - Winemaking and Wine Growing, 2001, no. 4, pp. 9-11.

20. Mesters M., Busto O., Guasch J. Analysis of organic sulfur compounds in wine aroma // J. Chromat. A. 2000. V. 881. P. 569581.

21. Ball $\mathbf{S}$. HPLC analysis of organic acids in wine // LC-GC Nor. Amer. 2008. № 2.

22. Prosen H., Strlic M., Kocar D., Rusjan D. In vivo veritas- LC-MS in wine analysis // LC-GC NA. 2008. № 2.

23. Mateo J.J., Jimenez M. Monoterpenes in grape and wines // J. Chromat. A. 2000. V. 881. P.557-567. 
организаторы

ФОРУМ И ВЫСТАВКА

Метрол

1. МИНПРОМТОРГ

РОССИИ

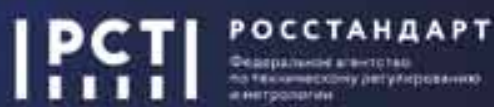

162 22 MaЯ

圆 КРОКҮС ЭКСПО

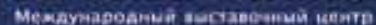

МЕЖДУНАРОДНЫЙ ИННОВАЦИОННЫЙ ФОРУМ И ВЫСТАВКА, ПРИУРОЧЕННЫЕ К ВСЕМИРНОМУ ДНЮ МЕТРОЛОГИИ. 20-22 МАЯ 2020 ГОДА, МВЦ «КРОКУС ЭКСПО»

ОРГАНИЗАТОРЫ - Минпромторг России и Росстандарт при поддержке Правительства Российской Федерации

\section{В ДЕЛОВОЙ ПРОГРАММЕ МЕТРОЛЭКСПО 2020}

- Панельная дискуссия с участием руководства Минпромторга

России и Росстандарта

- Открытые дискуссии в формате круглых столов по темам метрологического обеспечения нацпроектов, цифровой метрологии, законодательным новациям в области обеспечения единства измерений, импортозамещению

- Всероссийский съезд приборостроителей и метрологов

\section{НА ТЕРРИТОРИИ ВЫСТАВОЧНОЙ ЧАСТИ МЕТРОЛЭКСПО 2020:}

- Новейшие отечественные и зарубежные образцы и разработки в области приборостроения

- Уникальные установки, технологии и сервисы, созданные научными метрологическими институтами и центрами стандартизации, метрологии и испытаний системы Росстандарта, а также ведущими отечественными и зарубежными предприятиями

\section{РЕГИСТРАЦИЯ УЧАСТНИКОВ}

ПРИЕМ ЗАЯВОК до 1 марта 2020 года по адресу: forum2020@vniims.ru Информация об участии: 8 (495) 4374061

Подробности на www.vniims.ru

Официальный оператор Форума и Выставки ФГУП ВНИИМС 
24. Gu X., Chu Q., Dwuer M., Zeece M. Analysis of resveratrol in wine by capillary electrophoresis // J. Chromat. A.2000. V. 881. P. 471481.

25. McDonald M.S., Hughes M., Burns J. et al. Survey of thefree and conjugated myricetin and quercetin of red wine of different geographical origin // J. Agric.Food Chem. 1998. V. 46. P. 368375 .

26. Guadalupe L., Soldevilla A. et al. Analysis of polymeric phenolics in red wines using different techniques combined with gel permeation chromatography fractionation // J. Chromat.A. 2006. V. 1112. P. 112-120.

27. Revilla E., Ryan J.-M. Analysis of several phenolic compounds with potential antioxidant properties in grape extracts and wines by HPLC-photodiode array detection without sample preparation // J. Chrmat. A. 2000. V. 881. P. 461-469.

28. Arribas A.S., Martinez-Fernandez M., Chicharro M. The role of electroanalytical techniques in analysis of polyphenols in wine // $\mathrm{Tr}$ AC. 2013. V. 34. P. 78-96.

29. Perez-Alvarez E.P., Garcia R., Barrulas P. et al. Classification of wines according to several factors by ICP-MS multi-element analysis // Food Chem. 2019. V. 270. P. 273-280.

30. Azzi-Achkouty S., Estephan N. et al. Headspace solid-phase microextraction for wine volatile analysis // Crit. Rev. Food Sci. Nutr. 2017. V. 57. P. 2009-2020.

31. Aru V., Sorensen K. M., Khakimov B. et al. Cool-climate red wines-chemical composition and comparison of two protocols for H-NMR analysis // Molecules. 2018. V. 23. P. 160.

32. Guo Y.Y., Yang Y.P., Peng Q., Hon Y. Biogenic amine in wine.A review // Int. J. Food Sci Tech. 2015. V. 50 p. 1523-1532.

33. Blanco-Vega D., Lopez-Bellido F.J. et al. HPLC-DAD-ESI-MS characterization of proanthocyanidins pigments formed in model wine // J. Agric.Food Chem. 2011. V. 59. P.9523-9531.

34. Lin J., Zhu Y., Cheng W. et al. Determination of free and total sulfite in red globe grape by ion chromatography // Food Sci. Tech. Res. 2014. V. 20. P. 1079-1085.

35. Nobrega I.C.C., Pereira G.E., Silva M. et al. Improved sample preparation for GC-MS-SIM analysis of ethyl carbamate in wine // Food Chem. 2015. V. 177. P. 23-28.

36. Fernandez-Mar M.T., Mateos R et al. Bioactive compounds in wine-resveratrol, hydroxytirosol and melatonin. A review // Food Chem. 2012. V. 130. P. 797-813.

37. Concalves J., Silva C. L., Castilho P.C., Camara J.S. An attractive, sensitive and high-throughput strategy based on microextraction by packed sorbent followed UHPLC-PDA analysis for quantification of hydroxybensoic and hydroxycinnamic acids in wines // Microchemical J. 2013. V. 106. P. 129-138.

38. Jeffery D.W., Parker W., Smith P.A. Flavonol composition of Australian red and white wines determined by HPLC // Aust. J. Grape Wine Res. 2008. V. 14. P. 153-161.

39. Ahammad B., Abedin M.M. Predicting wine types with different classification techniques // MjdelAssissted Stat. Appl. 2018. V. 13. P. 85-93.

40. Sourina J. Characterization of wines using compositional profiles and chemometrics // Trac. -Trend. Anal Chem. 2010. V. 29. P. 234-245

41. Барашков Г. Винотерапия в СПА // Les nouvellesesthetiques. 2010 № 2. P. 3-16

Barashkov G. Wine Therapy in SPA. Les nouvellesesthetiques. 2010, no. 2. P. 3-16.

42. de Villiers A, Vanhoenacker G, Majek P, Sandra P. Determination of anthocyanins in wine by direct injection liquid chromatographydiode array detection-mass spectrometry and classification of wines using discriminant analysis. J Chromatogr A. 2004. V.1054 (1-2). P.195-204.

43. Fuhrman B, Volkova N, Suraski A, Aviram M. White wine with red wine-like properties: increased extraction of grape skin polyphenols improves the antioxidant capacity of the derived white wine. J Agric Food Chem. 2001. V.49 no 7. P. 3164-3168.

44. Paolo Simonetti, PiergiorgioPietta, GiulioTestolin Polyphenol Content and Total Antioxidant Potential of Selected Italian Wines
Journal of Agricultural and Food Chemistry .1997. V.45 (4). P. 1152 1155 .

45. Berente B., De la CalleGarcía D., Reichenbächer M., Danzer K. Method development for the determination of anthocyanins in red wines by high-performance liquid chromatography and classification of German red wines by means of multivariate statistical methods. J Chromatogr A. 2000 V. 871(1-2). P.95-103.

46. Яшин А.Я., Яшин Я.И., Черноусова Н.И. Антиоксиданты в красном вине и их определение амперометрическим методом // Виноделие и виноградарство. 2007 № 6. С. 22-23.

Yashin A.Ya., Yashin Ya.I., Chernousova N. I. Antioxidants in Red Wine and Their Determination by Amperometric Method. Vinodelie i vinogradarstvo - Winemaking and Wine Growing, 2007, no. 6, P. 22-23.

47. Яшин Я.И., Рыжнев В. Ю., Яшин А. Я., Черноусова Н. И. Природные антиоксиданты. Содержание в пищевых продуктах и их влияние на здоровье и старение человека. Москва. ТрансЛит. 2009. 212 с.

Yashin Ja.I., Ryzhnev V.Ju., Yashin A. Ja., Chernousova N.I. Natural antioxidants. Food Content and Its Effects on Human Health and Ageing. Moscow.TransLitPubl., 2009, 212 p.

48. Яшин А.Я., Черноусова Н. И., Труханов А.И., Чертушкин В. С., Фрейдкина Е. В. Определение транс- и цис ресвератролов в винах методом ВЭЖХ с амперометрическим детектированием. Виноделиеивиноградарство. 2011. № 6. C. 43-45.

Yashin A. Ya., Chernousova N.I., Truhanov A.I., Chertushkin V.S., Freidkina E. V. Determination of trans- and cis resveratrol in wines by HPLC with amperometric detection. Vinodelie i vinogradarstvo - Winemaking and Wine Growing, 2011, no. 6. P. 43-45.

49. Di Lorenzo C., Bodea M., Colombo F. et al. Antioxidant activity of wine assessed by different in vitro methods // Bio web of Conference. 2017.V.9. 04008

50. Fassonla E., Economou A., Calokerines A. Development and validation of a sequential injection method with chemiluminescence assay of the total antioxidant capacity of wine // Talanta. 2011.V.85. P.1412-1418.

51. Giammanco M., De Majo D. The antioxidant capacity of red wine in relationship with its polyphenolic constituents // Food Chem. 2008. V.111 .P. 45-49.

52. Thaipong K., Boonprakob U., Crosby K. et al. Comparison of ABTS DPPH, FRAP and ORAC assays for estimating antioxidant activity // J. Food Compos. Anal. 2006.v.19, p.669-675.

53. Sabat S., Chaitra L.M., Ranjitha R. Evoluation of antioxidant and antimicrobial activity of wine from various sources // Int. J. Curr. Microbiol. App. Sci. 2016. V.5.p.26-35.

54. Seruga M., Novak I., Jakobik L. Determination of polyphenol contents and antioxidant activity of some red wine by differential pulse voltammetry, HPLC and spectrophotometric methods // Food Chem. 2011.v.124. p.1208-1216.

55. Tubaro F., Pizzuto R., Raino G., Paventi G. A novel fluorimetricmethod to evaluate red wine antioxidant activity // PeriodicaPolytech. Chem. Eng. 2019. V.69. p.57-64.

56. Buyuktuncel E., Porgali E., Colak C. Comparison of total phenolic content and total antioxidant activity in local red wine determined by spectrophotometric methods // Food Nutr. Res. 2014. V.5. p.1660-1667.

57. Muselic J., Garcia-Alonso M., Martin-Lopez M.P. Measurement of antioxidant activity of wine catechins, procyanidins, anthocyanins and pyranoanthocyanidins // Int. J. Mol. Sci. 2007.v.8. p.797809.

58. Mannino S., Brenna O., Buratti S., Casio M.S. A new method for the evaluation of the antioxidant power of wines // Electroanalysis. 1998 v.10. p.908-912.

59. Kharadze M., Japaridze I., Kalendia A., Vanidze M. Anthocyanins and antioxidant activity of red wines made from endemic grape varieties // Annals of Agrarian Science. 2018. V.16.p.181-184.

60. Агеева Н.М., Бурлака С. Д., Музыченко Г. Ф. Антиоксидантная активность фенолокислот в красных столовых винах // Научные труды КубГТУ. 2016.№ 3 С. 7-12. 
Ageeva N.M., Burlaka S.D., Muzychenko G.F. Antioxidant Activity of Phenolacids in Red Table Wines. Nauchnye trudy KubCTUScientific works of KUBGTU, 2016, no. 3, P.7-12.

61. Ульянова Е.В., Ларионов О.Г., Ревина А.А. ВЭЖХ в исследованиях антиоксидантных свойств вин // Сорбционные и хроматографическиепроцессы. 2010.т.10. с. 522-532.

Ul'janova E.V., Larionov O.G., Revina A.A. HPLC in Studies of the Antioxidant Properties of Wines.Sorbcionnye i hromatograficheskieprocessySorption and chromatographic processes. 2010, V.10, P.522-532.

62. Лапин А. А., Горбунова Е. В., Зеленков В.Н., Герасимова М.К. Определение антиоксидантной активности вин кулонометрическим методом (Научно-методическое пособие). Москва. Издание РАЕН. 2009. 64 с.

Lapin A. A., Gorbunova E.V., Zelenkov V.N., Gerasimova M.K. Determination of Antioxidant Activity of Wines by Coulonometric Method (Scientific and Methodical Manual). Moscow. RAENPubl., 2009, 64 p.

63. Агеева Н. М., Маркосов В.А., Бессонов В. В., Хапферьян Р.А. Антиоксидантные и антирадикальные свойства красных виноградных вин // Вопросы питания. 2015. № 2. С. 63-67 Ageeva N. M., Markosov V.A., Bessonov V.V., Hapfer'jan R. A. Antioxidant and Anti-radical Properties of Red Grape Wines. Voprosypitanija - Food questions, 2015, no. 2, P.63-67.

64. Лапин А.А. Оценка антиоксидантной активности вин // Индустрия напитков. 2008.№ 5.c.118-122. Lapin A. A. Evaluation of antioxidant activity of wines. Industrijanapitkov-Industry of drinks, 2008, no. 5, P. 118-122.

65. Vinson J.A., Hontz B.A. Phenol antioxidant index: comparative antioxidant effectiveness of red and white wines // J. Agric.Food Chem. 1995. V.43. no 2. P.401-403.

66. Katalic V., Milos M., Modun D. et.al. Antioxidant effectiveness of selected wines in comparison with (+)-catechin // Food Chem. 2004. V.86. P.593-600.

67. Ghiselli A., Nardini M., Baldi A. et.al. Antioxidant activity of different phenolic fraction separated from Italian red wine // J. Agric.Food Chem. 1998. V.46. p.361-367.

68. Kekelidze K.N. et al. The content of antioxidants-phenolic compounds in red wines of Georgia "kinzmarauli" and "saperavi" // Appl. Food Sci. J. 2018.V.2.P.18-22.

69. Baydar N.G., Balalik Z., Turk F.H., Cetin E.S. Phenolic composition and antioxidant activitys of wines and extracts of some grape varieties grown in Turkey // J. Agric Sci. 2011v.11. P.6776.

70. Papachatzis A., Guoyoulias N., Helen K. et al. Studies of total phenol contents, anthocyans and antioxidant activity of some greek red wines // University of Craiova. 2010. V.15.

71. Ghatak A.A., Chatarvedi P.A., Desai N.S. Indian grape wines a potential sources of phenols, polyphenols and antioxidants // Int. J. Food Proper. 2014. V.17. P.818-828.

72. Campos A.M., Lissi E. A. Total antioxidant potential of Chilean wines // Nutr.Res. 1996. V.16. p.385-389.

73. De Beer D., Joubert E., Gelderblom W.C.A. et al. Antioxidant activity of South African red and white cultivar wines. - free radical scavenging // J. Agric Food Chem. 2003 .V.51. P.902-909.

74. Landrault N., Poucheret R., Ravel P. et al. Antioxidant capacities and phenolics levels of French wines from different varieties and vintages // J Agric. Food Chem. 2001. V. 49. P. 2341-2348.

75. Simonetti P., Pietta P., Testolin G. Plyphenolcontent and total antioxidant potential of selected Italian wines. J. Agric Food Chem.1997.V.45.P.1152-1155.

76. Jordano A.M., Simoes S., Correia A.C. et al. Antioxidant activity evolution during Portuguese red wine vinification and their relation with proanthocyanidin and anthocyanin composition // J. Food Proc. Preser. 2012.V.36. P.298-309.

77. Fanzone M., Pena-Neira A., Gil M. et al. Impact of phenolic and poly saccharidiccomposition on commercial value of Argentinean Malbec and Cabernet Souvignon wines // Food Res. Int. // 2012.V.45. P. 402-414.

78. Piljac J., Martinez S., Valek L. et al. A comparison of methods used to define the phenolic content and antioxidant activity of Croatian wines // Food Technol. Biotechnol. 2015.V.43. P. 271-276.

79. Fernandez de Simon B. T., Herrandez E. et al. Phenolic compounds in a Spanish red wine aged in barrels made of Spanish, French and American oak wood // Eur. Food Res. Tech. 2003.V.216. P. 150-156.

80. Stasko A., Brezova V., Masur M. et al. A comparative study of the antioxidant properties of Slovakian and Austrian wines // LWT-Food Sci. Techn. 2008. V.41. P.2126-2135.

81. Mitic M.N., Kostic D. A., Pavlovic A.M. The phenolic composition and the antioxidant capacity of Serbian red wines // Adv. Techn. 2014. V.3. P.16-22.

82. Tarko T., Duda-Chodak A., Sroka P. et al. Physicochemical and antioxidant properties of selected polish grape and fruit wines // Acta Sci. Pol. Techn. Aliment. 2008.V.7. P.35-45.

83. Li H., Wang X., Li Y., Li P., Wang H. Poliphenolic compounds and antioxidant properties of selected china wines // Food Chem 2009. V. 112.P. 454-460.

84. Lachman J., Sulc M., Shilla M. Comparison of the total antioxidant status of Bohemian wines during the wine-making process // Food Chem.2007.V.103. P.802-807.

85. Lucena A.P.S., Nascimento R.J.B., Maciel J. A. et al. Antioxidant activity and phenolic contents of selected Brazilian wines // J. Food Compos. Analysis 2010. V.23. P.30-36.

86. Dordevic N. O., Novacovic M.M., Pejin B. et al. Comparative analytical study of the selected wine varieties grown in Montenegro // Nat. Prod. Res. 2017.V. 31. P. 1825-1830.

87. Агеева Н.М., Бурлака С. Д., Музыченко Г.Ф. Антиоксидантная активность фунолокислот в красных столовых винах // Научные труды КубГТУ. 2016. № 13. С. 7-12. Ageeva N.M., Burlaka S.D., Muzychenko G.F. Antioksidantnajaaktivnost' funolokislot v krasnyhstolovyhvinah // NauchnyetrudyKubGTU. 2016. № 13. P. 7-12.

88. Schmitzer V., Veberic R., Slatnar A., Stampar F. Elderberry wine. A product rich in health promoting compounds // J. Agric Food Chem. 2010. V.58. P.10143-10146.

89. Romalho S. A. et al. Catechin and epicatechin contents I wines obtained from Brazilian exotic tropical fruits // Foods and Nutr. Sci.2014.V.5 P.5.

90. Tao Y., Wang Y., Yang J. et al. Chemical composition and sensory profiles of mulberry wines as fermented with different saccharomyces cerevisial strains // Int. J. Food Proper. 2017.V.20.P.2006-2021.

91. Rathi V. Herbal wine-a review // J. Nutr. Weight Losc. 2018. V.3 P.113.

92. Joshi V.K. Fruit wines. $2^{\text {nd }}$ ed. Directorate of extension education, India. 1997.

93. McGovenn P.E., Mizzaian A., Gretchen R. Ancient Egyptian herbal wines // Proc. Natl. Acad. Sci. 2009. V.106. P. 7361-7366

94. Mena P. Assessment of the melatonin production in pomegranate wines // J. Food Sci. Technol. 2012. V.17. P.13-18.

95. Joshi V.K., Kumar V. Influences of different sugar sources, nitrogen sources and incula on the quality characteristics of apple tea wine // J. Int Brew. 2017.V.123. P.268-276.

96. Yoo Y.J., Saliba A.J., Prenzler P.D., Ryan D. Total phenolic content, antioxidant activity and cross-cultural consumer rejection threshold in white and red wines functionally anhanced with catechin-rich extracts // J. Agric. Food Chem. 2012.V.60.P.388-393.

97. De Rosso M. et al. Changes in chemical composition of a red wine aged in acacia, cherry, chestnut, mulberry and oak wood barrels // J. Agric. Food Chem. 2009.V.57. P.1915-1920.

98. Negi B., Gargi D. Comparative analysis of total phenolic content in sea buckthorn wine and other selected fruit wines // World Acad. Sci. Eng. Techn. 2009. V.54. P.396-399.

99. Alakon M.E., Perez-Coello M.S., Marina M.L. Wine science in the metabolomics era // Tr AC. 2015. V.74.P.1-20.

100. Hong Y. S. NMR-based metabolomics in wine science // Magn. Reson. Chem. 2011. V.49. 
101. Artero A., Artero A., Tarin J.J., Cano A. The impact of moderate wine consumption on health // Maturitas. V.80.P.3-13.

102. Snopek L., Micek J., Sochorova L. et al. Contribution of red wine consumption to human health protection // Molecules. 2018.V.23. no 7. P.1684.

103. Golan R., Gerner Y., Shai I. Wine and health-new evidence // Eur. J. Clin. Nutr. 2019. V.72.P.55-59.

104. Staff U. The Health benefits of red wine. Scientific evidence is compelling // Nutrition. 2017.

105. Guifford J.M., Pezzuto J.M. Wine and health. A review // Am. J. Enol. Vitic. 2011. V.62. P.471-486.

106. Pavlidou E., Mentzorou M, Fasoulos A. et al. Wine- An aspiring agent to promoting longevity and preventing chronic diseases // Diseases. 2018. V.6.P.73.

107. Alexandre J., Alexandre-Tudo J. et al. Mapping the scientific research on wine and health (2001-2011) // J. Agric. Food Chem. 2013. V.61. P.11871-11880.

108. Wurz D.A. Wine and health- a review of its benefits to human health // Bio web conf. 2019. V.12. 04001.

109. Feher J., Lenguello G., Lugasi A. The cultural history of wine theoretical background to wine therapy // Central Eur. J. Med. 2007. V.2.P.379-391.

110. Mortreux M., Riveros D., Bouxsein M.L. and Rutkove S. B. A Moderate Daily Dose of Resveratrol Mitigates Muscle Deconditioning in a Martian Gravity. Analog. Front. Physiol.,2019. 18 doi.org/10.3389/fphys.2019.00899.

111. Fernandes I., Perez- Gregorio R., Soares S. et al. Wine flavonoids in health and diseases prevention // Molecules. 2017. V.22. P.292.

112. Liberale L., Bonaventura A., Montecucco F. et al. Impact of red wine consumption on cardiovascular health // Curr.Med. Chem. 2017.

113. Cordova H.C., Jackson L. S. et al. The cardiovascular protective effect of red wine // J. Am. Coll. Surg. 2005. V.200.P.428-439.

114. Mohamed Saleem TS. Red wine: a drink to your heart.JCardiovasc Dis Res. 2010; 1:171-176. doi: 10.4103/0975-3583.74259.

115. Markoski M.M., Garavaglia J., Oliveira A., Olivaes J., Marcadenti A. Molecular properties of red wine compounds and cardiometabolicbenefits.NutrMetab Insights. 2016; 9:51-57. doi: $10.4137 /$ NMI.S32909.

116. Haseeb // Circulation 2017. V.136.P.1434-1448.

117. Iriti M., Varoni E.M. Cardioprotective effects of moderate red wine consumption: polyphenols vs. ethanol.JAppl Biomed. 2014; 12:193202. doi: 10.1016/j.jab.2014.09.003.

118. Goldberg I.J., Mosca L., Piano M. R., Fisher E. A. Wine and your heart.Circulation. 2001; 103:472-475. doi: 10.1161/01. CIR.103.3.472.

119. Lippi G., Franchini M., Favaloro E. J., Targher G. Moderate Red Wine Consumption and Cardiovascular Disease Risk: Beyond the French Paradox. Semin. Thromb. Hemost. 2010, 36, 59-70.

120. Carrolo C., Presti R. Wine, diet and arterial hypertension // Angiology. 2007.V.58. P.92-96.

121. Kondo K., Matsumoto A., Kurata H. et al. Inhibition of oxidation of low-density lipoproteins with red wines // The Lancet. 1994. V.344.p.1152.

122. Stephan L.S., Almeida E. D., Markoski M. M. et al. Red wine, resveratrol and atrial fibrillation // Nutrients. 2017. V. 9. P. 1190.

123. He S., Sun C., Pan Y. Red wine polyphenols for cancer prevention // Int. J. Mol. Sci. 2008.V.9. P.842-853.

124. Damianaki A., Bakogeorgan E., Kampa M. et al. Potent inhibitory action of red wine polyphenols on human breast cancer cells // J. Cell Biochem. 2000. V.78.P.429-441.

125. Amor S., Chalons P., Aires V., Delmas D. Polyphenol extracts from red wine and grape vine potential effects on cancer // Diseases. 2018. V.6. P.106.

126. Arranz. S., Chiva-Blanch G., Valderas-Martinez P., MedinaRemon A., Lamuela-Raventos R.M., Estruch R. Wine, Beer, Alcohol and Polyphenols on Cardiovascular Disease and Cancer. Nutrients. 2012. 4. P.759-781.
127. Vartolomei M.D., Kimura S., Ferro M., Foerster B., Abufaraj M., Briganti A., Karakiewicz P.I., Shariat S.F. The Impact of Moderate Wine Consumption on the Risk of Developing Prostate Cancer. Clin. Epidemiol. 2018. V. 10. P.431-444.

128. Caimi G., Carollo C., Lo Presti R. Diabetes mellitus-oxidative stress and wine // Curr. Med. Res. Opin. 2003. V.19.P.581-586.

129. Presti R.L., Carollo C., Caimi G. Wine consumption and renal disease. New perspectives // Nutrition. 2007. V.23. p.598-602.

130. Caruana M., Canchi R., Vassallo N. Putative role of red wine polyphenols against brain pathology in Alzheimer and Parkinson disease // Front. Nutr. 2016.V.3. P.31.

131. Basli A., Soulet S., Chaher N. et al. Wine polyphenols-potential agents in neuroprotection // Oxid. Med. Cell Longev. 2012. 805762.

132. Rodrigo R., Miranda A., Vergara L. Modulation of endogenous antioxidant system by wine polyphenols in human disease // ClinicaChim. Acta. 2011.V.412. P.65-69.

133. Marwell S., Cruickshank A., Thorpe G. Red wine and antioxidant activity in serum // The Lancet. 1994. V. 344. P. 193-194.

134. Grujic-Melanovic, Melanovic Z., Jonovic D. et al. The red wine polyphenol, resveratrol improves hemodynamics, oxidative defense and aortal structure in essential and malignant hupertension // J. Funct. Foods 2017.V.34.P.266-276.

135. Di Lorenzo D.C.S., Colombo F., Biella S. et al. The role of wine in modulating inflammatory processes- a review // Beverages. 2018.V.4.P.1-17.

136. Esteban-Fernandez A., Zirraquin-Pena I, et al. The role of wine and food polyphenols in oral health // Trends. Food Sci. Technol. 2017. V. 69. P. 118-130.

137. Biasi F., Deiana M., Guina T. et al. Wine consumption and intestinal redox homeostasis // Redox Biol. 2014. V. 2. p. 795802.

138. Diaz-Cruz C., Chua A.S., Malik M.T. et al. The effect of alcohol and red wine consumption on clinical MPI outcomes in multiple sclerosis // Multiple sclerosis and related disorders. 2017.V. 17. P. 47-53.

139. Nash V., Ranodheero S.C. et al. The effect of grape and red wine polyphenols on gut microbiota. Asystematicreview // FoodRes. Int. 2018.

140. Covas M.I., Gambert P., Fitó M., de la Torre R. Wine and oxidative stress: up-to-date evidence of the effects of moderate wine consumption on oxidative damage in humans. Atherosclerosis. 2010; 208:297-304. doi: 10.1016/j.atherosclerosis. 2009.06.031.

141. Daroch F., Hoeneisen M., González C.L., Kawaguchi F., Salgado F., Solar H., García A. In vitro antibacterial activity of Chilean red wines against Helicobacter pylori. Microbios. 2001;104(408):79-85.

142. Tanaka T., Iuchi A., Harada H., Hashimoto S. Potential Beneficial Effects of Wine Flavonoids on Allergic Diseases. Diseases. 2019 Jan $15 ; 7(1)$.

143. Zorraquín-Pena I., Esteban-Fernández A., González de Llano D., Bartolomé B., Moreno-Arribas M. V. Wine-Derived Phenolic Metabolites in the Digestive and Brain Function. 2019. Beverages. 5. 7. 10.3390 / beverages5010007.

144. Esteban-Fernández A., Zorraquín-Pena I., González de Llano D., Bartolomé B., Moreno-Arribas M.V. The role of wine and food polyphenols in oral health, Trends in Food Science \& Technology. 2017. V. 69, Part A. P. 118-130.

145. Pavlidou E., Mantzorou M., Fasoulas A., Tryfonos C., Petridis D., Giaginis C. Wine: An Aspiring Agent in Promoting Longevity and Preventing Chronic Diseases. Diseases. 2018 Aug 8;6(3). pii: E73.

146. Bucher T., Deroover K., Stockley C. Low-Alcohol Wine: A Narrative Review on Consumer Perception and Behaviour. Beverages 2018, V. 4. P. 82. https://doi.org/10.3390/ beverages 4040082 . 


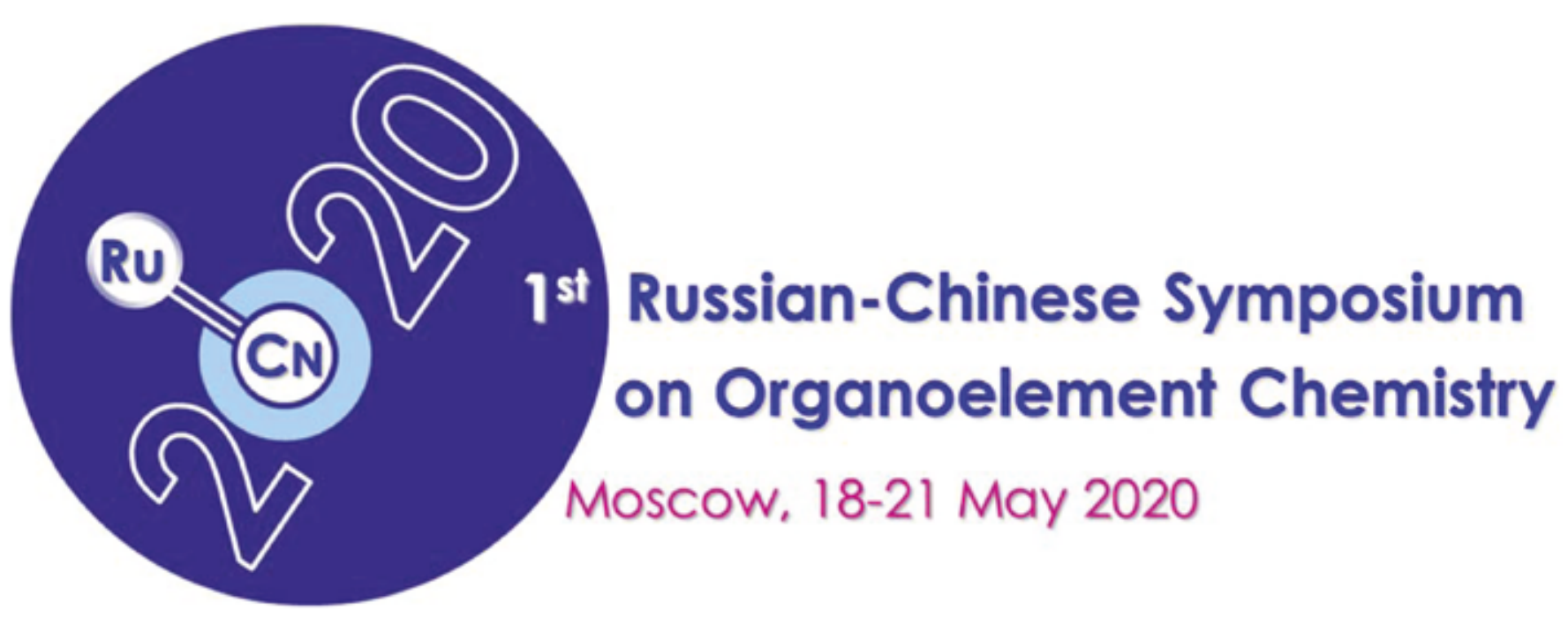

Глубокоуважаемые коллеги!

Институт элементоорганических соединений им. А.Н. Несмеянова РАН совместно с Государственной целевой лабораторией по элементоорганической химии Нанкайского университета (г. Тяньцзинь, Китай) приглашает Вас принять участие в 1-м Российско-Китайском симпозиуме по әлементоорганической химии. Симпозиум направлен на развитие устойчивого долгосрочного российско-китайского сотрудничества, расширение научного взаимодействия и обмена информацией о результатах исследований в различных областях элементоорганической химии; развитие внутрироссийской и международной коммуникации между научным, образовательным, и бизнес-сообществами, обсуждение возможности выполнения совместных проектов и создания совместной российско-китайской лаборатории по проблемам элементоорганической химии.

\section{Основные тематические направления Симпозиума:}

- элементоорганическая и координационная химия

- гомогенный и гетерогенный катализ

- элементоорганические полимеры и функциональные материалы

- супрамолекулярная химия

- элементоорганические и макромолекулярные соединения для химии материалов

Программой конференции предусмотрены пленарные доклады ведущих российских и китайских ученых, устные сообщения и стендовые сессии.

Актуальная информация о Симпозиуме и условиях участия - на сайте www.ineos.ac.ru

Будем рады видеть Вас среди участников Симпозиума!!! 